\title{
Veiksniai, darantys įtaką kultūrinio agrarinio kraštovaizdžio pokyčiams Lietuvoje
}

\author{
Pranas Aleknavičius \\ Aleksandro Stulginskio universitetas, \\ Studentug. 11, \\ LT-53361 Akademija, Kauno r. \\ El.paštas pranas.aleknavicius@gmail.com
}

\begin{abstract}
Aleknavičius P. Veiksniai, darantys įtaką kultūrinio agrarinio kraštovaizdžio pokyčiams Lietuvoje. Geologija. Geografija. 2017. T. 3(1). ISSN 2351-7549.

Straipsnyje apibūdinti kaimiškojo agrarinio kraštovaizdžio elementai, išnagrinètos jų pokyčius lemiančios priežastys. Pagrindinès priežastys - valstybès vykdyti esminiai žemès ūkio naudmenų pagerinimo darbai, valstybès skatinama žemès naudotojų veikla ir demografiniai procesai. Didžiausi pokyčiai formuojant stabilius agrarinio kraštovaizdžio elementus vyko 19601990 m. Mažiau stabilių kraštovaizdžio elementų - žemès naudmenų plotų kaita vyksta nuolat, per 1946-2016 m. žemės ūkio naudmenų plotas Lietuvoje sumažèjo 19,8 \%, miškų plotas padidèjo 82,8 \%. Formuojant kultūrini kaimiškajji kraštovaizdi svarbią reikšmę turi teritorijų planavimo dokumentai. Vadovaujantis šių dokumentų sprendiniais, nustatomi žemés naudojimo apribojimai bei sąlygos tam tikrai kraštovaizdị keičiančiai veiklai. Straipsnyje pateikiami pasiūlymai, kad planuojant agrarines teritorijas turètų būti panaudojami Žemès ịstatyme numatyti kaimo plètros žemètvarkos projektai. Projektuose būtų kompleksiškai sprendžiamos priemonès, pagerinančios techninę infrastruktūrą, dirbamos žemès laukų ir miško sklypų formavimą, apleistų ir dirvonuojančių žemès plotų tolesnį panaudojimą, taip pat priemonès, padidinančios ekologinę ivvairovę. Šių projektų panaudojimas kraštovaizdžio tvarkymui reguliuoti užtikrintų racionalų žemès naudojimą ir leistų išvengti vertingų kraštovaizdžio elementų nykimo.
\end{abstract}

Raktažodžiai: žemès ūkio paskirties žemé, žemès naudmenos, techninė infrastruktūra, agrarinis kraštovaizdis, ekologinè ịvairovè

\section{IVADAS}

Kultūriniu agrariniu kraštovaizdžiu šiame straipsnyje vadinamas žemès ūkio veiklos požymių turintis (t. y. išskyrus urbanizuotas teritorijas, miškų ir pelkių masyvus bei stambius vandens telkinius) kaimiškasis kraštovaizdis, kurio formavimui padare ittaką racionalus teritorijos tvarkymas ir žemès gerinimo priemonès. Toks kultūrinio agrarinio kraštovaizdžio apibūdinimas atitinka Lietuvos Respublikos kraštovaizdžio politikos krypčių apraše (Lietuvos Respublikos..., 2004c) pateiktą kultūrinio kraštovaizdžio sąvoką: „Kultūrinis kraštovaizdis - teigiamas žmogaus ir aplinkos darnaus sambūvio rezultatas. Tai kryptingai formuojamas, tenkinantis biologinius, psichologinius, socialinius, ergonominius (tinkamumo veiklai), ekonominius gyvenamosios, darbo ir poilsio aplinkos kokybès poreikius kraštovaizdis."

Agrarinèse teritorijose, atsižvelgiant i gamybos organizavimo specifiką, kraštovaizdis turètų būti vertinamas išanalizavus ūkių žemès valdų teritorinio tvarkymo sistemos komponentus (sodybos, keliai, melioracijos įrenginiai, dirbamos žemès laukai, sodų, pievų ir ganyklų sklypai), taip pat šioje teritorijoje tam tikru santykiu išsidèsčiusius vandens telkinius, apsauginius želdinius, kitų natūralių arba sąlyginai natūralių žemès naudmenų 
sklypus. Šiose teritorijose pagrindinius žemès plotus užima išskirtinès reikšmès gamtos ištekliai - žemès ūkio naudmenos su derlinguoju dirvožemiu, todèl tikslinga nustatyti, kiek kraštovaizdis pakito dèl natūralių, gamtinių procesų, taip pat dèl žemés naudotojų veiklos ir dèl valstybès finansuojamų darbų, kuriais buvo siekiama sukurti gyvybingų ūkių sistemą, išsaugoti našias žemès ūkio naudmenas ir padidinti ju produktyvumą. Analizuojant šios veiklos pasekmes, išskirtinos dvi agrarinio kraštovaizdžio elementų grupès: stabilūs (ilgalaikiai) elementai ir kintantys (sąlyginai nestabilūs) elementai.

Stabiliais elementais laikytini: gamtiniai objektai (vietovès reljefas, upès, upeliai, ežerai ir kt.) ir antropogeniniai, žmogaus sukurti objektai - sodybos, žemès ūkio ir kitos paskirties pastatai, keliai, tvenkiniai, kanalai, grioviai, hidrotechniniai statiniai. Kai kurie iš šių elementų yra išlikę dar nuo valakų reformos metu ìvykdytų teritorinių pertvarkymų, kiti atsirado dèl tarpukario žemès reformos arba po antrojo pasaulinio karo ịvykdytų totalinių melioracijos darbų. Visiems stabiliems antropogeniniams kraštovaizdžio elementams būdinga tai, kad šiuo metu jų sukūrimas naujoje vietoje arba pertvarkymas galimas tik labai nedidele apimtimi, kadangi tokie darbai reikalauja didelių kapitalinių investicijų, be to, prieš tai būtina parengti teritorijų planavimo dokumentą ir (arba) technini projektą.

Kintantiems kraštovaizdžio elementams priskirtinos ariamosios (dirbamos) žemès laukai, sodų sklypai, žoline augalija apaugę plotai, įskaitant daugiau kaip dvejus metus neartus dirbamos žemès sklypus (jie apibūdinami kaip apleista žemé, dirvonuojanti žemé, daugiamečių žolių pasèliai, pievos ir natūralios ganyklos), kitos kartografuojamos ir nekilnojamojo turto kadastro apskaitoje apibūdinamos žemès naudmenos. Šių žemès plotų virtimas kitomis naudmenomis yra palyginti dinamiškas ir vyksta tiek dèl natūralių gamtinių procesų, tiek dèl žmogaus veiklos.

Agrarinio kraštovaizdžio pokyčiai vyko visais laikais, tačiau šis procesas ypač suintensyvejjo pastaraisiais dešimtmečiais dèl politinių ir ekonominių permainų. Paminètinas 1940-1989 m. laikotarpis, kai svetimos valstybès valia Lietuvoje buvo nacionalizuota žemé, kuriamos stambios žemès ūkio įmonès, atlikti kompleksiniai žemès melioracijos darbai, pritaikę agrarines teritorijas pramoninei žemès ūkio gamybai, taip pat laikotarpis po 1991 m., kai žemès naudojimas kito dèl nuosavybès teisių ì žemę atkūrimo, buvusių kolūkių ir valstybinių ūkių transformacijos ị fizinių ir juridinių asmenų privačius ūkius, lešų stokos žemès ūkio plètrai ir žemès gerinimo darbams. Šiuos pokyčius nagrinèję mokslininkai nurodo priežastis, paveikusias agrarinę žemèvaldą ir kraštovaizdi po $1951 \mathrm{~m}$. Tai - pakeista žemès nuosavybès forma, kaimo gyventojų ir ypač darbingo amžiaus žmonių skaičiaus sumažejjimas, kaimo apgyvendinimo sistemos pertvarkymas, žemès dirbimo technikos ir technologijos modernejimas, sausinamoji melioracija (Ribokas ir kt., 2001). Prie neigiamų kraštovaizdị keičiančių pasekmių buvo priskiriama ir anksčiau dirbamos žemès apleidimas, virtimas kitomis naudmenomis: nors žemès ūkio paskirties žemès sklypu renatūralizacija kai kur padidino kraštovaizdžio ìvairovę, bet tai sumažino žemès vertę ūkinio naudojimo požiūriu; daugiausia tokių plotų yra mažesnio našumo dirvožemių ir žemès dirbimo požiūriu nepalankaus reljefo vietovèse - smèlingose lygumose bei moreniniuose kalvynuose (Balevičiūtè ir kt., 2012). Apleistų žemių plotai pradèti mažinti tik gavus ES paramą, todèl, jos netekus, Rytų Lietuvoje pradètų sparčiai didèti nenaudojamų žemių plotai (Ribokas ir kt., 2012).

Minèti tyrimai atlikti išanalizavus tik atskirus probleminius arealus. Todèl, siekiant išnagrinèti nuo XX a. 5-ojo dešimtmečio įvykusius kraštovaizdžio kitimo procesus šalyje, šiame straipsnyje atlikta statistinių rodiklių ir teisès aktu analizé, taip pat poreikio formuoti kultūrini agrarini kraštovaizdi rengiant žemètvarkos planavimo dokumentus analizè. Atliktų tyrimų tikslas - apibūdinti agrarinio kraštovaizdžio komponentų pokyčius Lietuvoje nuo didelès apimties melioracijos darbų vykdymo laikmečio iki šių dienų, išnagrinèti šiuos pokyčius lėmusias priežastis ir galimybes reguliuoti kultūrinio agrarinio kraštovaizdžio formavimosi raidą. Tyrimams panaudoti žemès valstybinès apskaitos rodikliai, kiti statistiniai duomenys, apibūdinantys melioracijos darbus, gyventojų skaičiaus ir žemès ūkio gamybos pokyčius, taip pat teisès aktai, susiję su parama žemès ūkio ir kaimo plètrai, bei reglamentuojantys agrarinio kraštovaizdžio pertvarkymą pagal teritorijų planavimo dokumentus. 


\section{KRAŠTOVAIZDŽIO POKYČIUS LEMIANTYS} VEIKSNIAI

Analizuojant priežastis, dèl kurių vyksta agrarinio kraštovaizdžio pokyčiai, išskirtos šios jų rūšys:

I. Valstybès vykdomi kompleksiniai melioracijos darbai.

II. Valstybės skatinama žemės naudotojų veikla.

III. Natūralūs (gamtiniai) procesai.

IV. Valstybès ir savivaldybių lygmens institucijų reguliuojama žemès naudotojų veikla.

V. Bendrųjų socialinių ir ekonominių pokyčių itaka žemès ūkio veiklai.

Nurodytų veiksnių poveikis Lietuvos agrariniam kraštovaizdžiui atskirais laikotarpiais nebuvo vienodas. Juos tiriant nustatyta didejantis teritorijų planavimo dokumentų poreikis tiek ilgalaikių, tiek sąlyginai nestabilių kraštovaizdžio elementų išdèstymui reguliuoti.

Valstybès įvykdyti kompleksiniai melioracijos darbai. Lietuvos istorijoje išskirti du periodai, kai valstybẻ vykdẻ užmirkusių žemių sausinimo darbus: 1) atvirais grioviais (tarpukariu) ir 2) drenažu (1960-1990). Antruoju laikotarpiu šie darbai ypatingi, nes buvo kompleksiškai tvarkoma visa melioruojama teritorija, pertvarkant arba sukuriant žemès ūkio veiklai reikalingą infrastruktūrą. Agrarinèse teritorijose, igyvendinant prieš tai parengtus žemètvarkos projektus, buvo ne tik formuojami taisyklingų kraštinių dirbamos žemès laukai, pritaikyti efektyviam žemès ükio technikos darbui, bet ir tiesiami nauji keliai su sankasa ir tvirta danga, ìrengiamos kultūrinès pievos ir ganyklos. Be to, valstybès léšomis buvo nukeliami seni vienkiemiai ir teikiama parama besikuriantiems kaimo gyvenvietėse. Žemès sausinimo darbų apimtys pateiktos 1 paveiksle.

Iš viso Lietuvoje iki $2016 \mathrm{~m}$. nusausinta (be miškų) 2664 tūkst. ha, arba apie $84 \%$ šlapių žemių fondo (pagal Respublikinio žemètvarkos projektavimo instituto $1984 \mathrm{~m}$. parengtą Lietuvos žemès resursų naudojimo generalinę schemą sausintinų žemès ūkio paskirties žemių plotas sudarè 3162 tūkst. ha). Iš to ploto drenažu nusausinta žemè $1960 \mathrm{~m}$. sudarè tik 191 tūkst. ha, o 2016 m. - 2576 tūkst. ha. Šie valstybès lèšomis vykdyti kompleksiniai žemès melioravimo darbai ilgam laikotarpiui sustiprino žemès ūkio

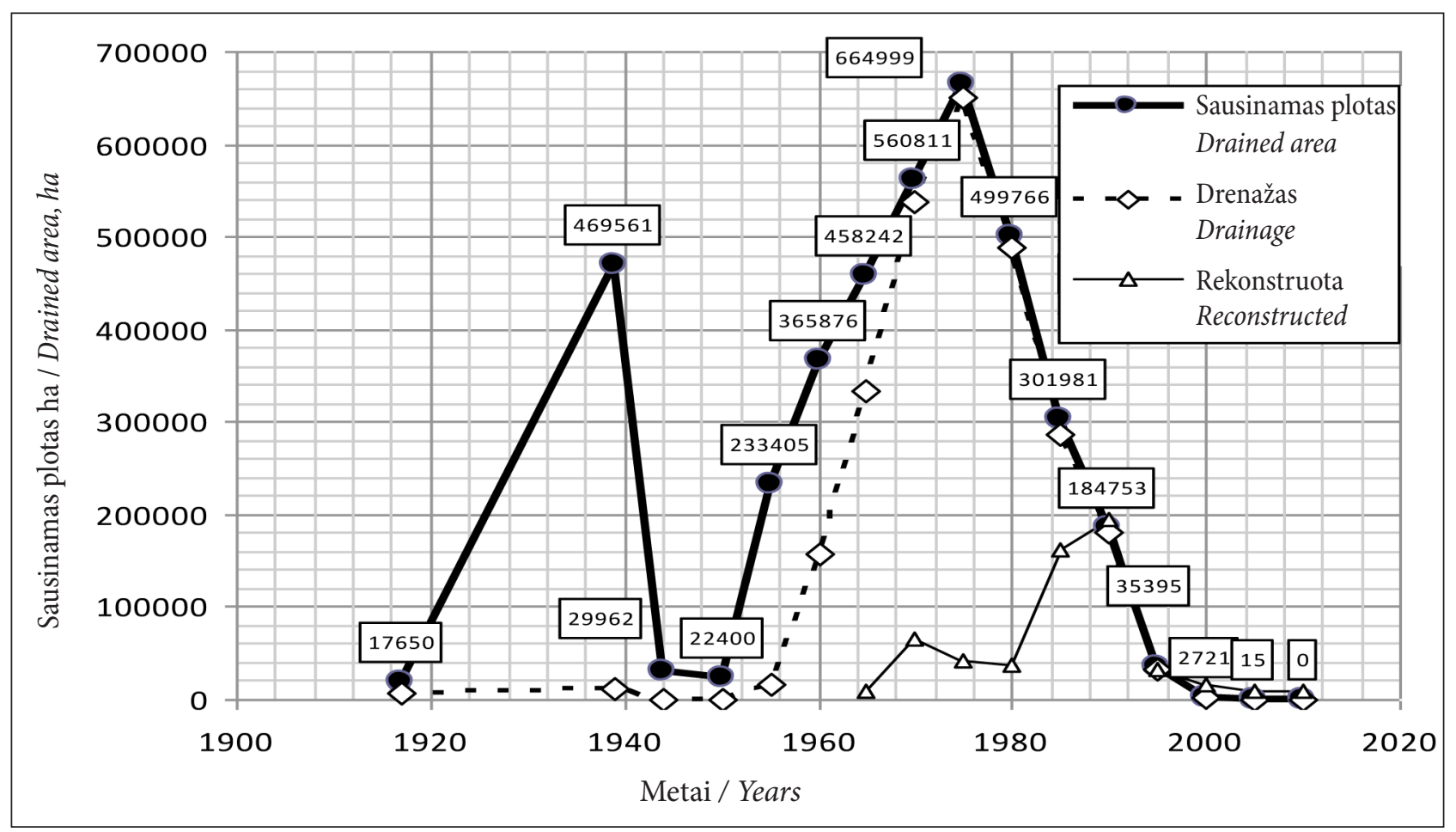

1 pav. Sausinamų plotų irengimo atskirais metų laikotarpiais apimčių kitimo dinamika

Fig. 1. The volume dynamics of drained areas installation during different periods

Šaltinis / Source: Gurklys Vidmantas. 2011. Žemès gerinimo darbai melioracinèmis priemonèmis. Iš: Žemés naudojimo priemonių mokslinis pagrindimas: 2011 m. baigiamoji ataskaita. Kaunas: LŽŪU. 
gamybini potencialą: leido išsaugoti dirbamos žemès plotus, pagerinti dirvožemio ūkines savybes, padidinti žemės našumą. Agrarinio kraštovaizdžio formavimo požiūriu jie daugiausia turèjo itakos šiuolaikinès kaimo apgyvendinimo sistemos ir žemès ūkio veiklai naudojamų plotų techninès infrastruktūros sukūrimui. Pažymètinos tokios naujai sukurtų arba pertvarkytų objektų apimtys:

- įrengta 52,4 tūkst. km magistralinių melioracijos kanalų ir 10,3 tūkst. $\mathrm{km}$ apsauginių griovių;

- nutiesta arba pagerinta 17,5 tūkst. km intensyviai naudojamų vietinès reikšmès kelių su sankasa ir tvirta danga;

- irrengti 359 tvenkiniai, kurių bendras plotas 13,7 tūkst. ha;

- nusausintose žemapelkèse ir kituose javų auginimui netinkamuose melioruotuose plotuose įrengta 217 tūkst. ha kultūrinių pievų.

Be to, atlikus dabartinès kaimo apgyvendinimo sistemos analizę nustatyta, kad kryptingo šios sistemos kūrimo dèka išvengta intensyvios žmonių migracijos $\mathfrak{i}$ miestus, stambesnèse nei 100 žmonių kaimo gyvenvietèse (jų yra 2,5 tūkst.) gyvena apie $73 \%$ visų kaimo gyventojų. Likusieji įsikūrę smulkesnèse gyvenvietèse ir vienkiemiuose (iš viso $2011 \mathrm{~m}$. Lietuvoje buvo 14,3 tūkst. tokių mažesnių kaimų ir viensèdžių). Stambiosios gyvenvietès išsidèsto beveik tolygiai visose administracinèse teritorijose ir pagal reikšmę pasiskirsto taip: priemiestinès gyvenvietès -682 , miesteliai -378 , buvusios žemès ūkio i̇monių centrinès gyvenvietès - 617, kitos stambios kaimo gyvenvietès, išaugę iš buvusių kaimų - 830 (Aleknavičius ir kt., 2014).

Po 1990 m. žemés melioravimo darbams Lietuvoje finansuoti didžioji dalis lèšų (apie $75 \%$ ) skiriama iš Europos Sąungos Europos žemès ūkio fondo kaimo plètrai, likusi dalis - iš nacionalinio biudžeto. Pagal Žemès ūkio ministerijos duomenis, iš Kaimo pletros programos melioracijos statiniams ir sistemoms rekonstruoti 2007-2013 m. programiniu laikotarpiu buvo išmokèta $111 \mathrm{mln}$. eurų, o 2014-2020 m. laikotarpiui numatyta dar mažiau - $87 \mathrm{mln}$. eurų. Šios lèšos panaudojamos daugiausia tik esamiems įrenginiams sutvarkyti ir atkurti. Visa tai turi įtakos agrarinio kraštovaizdžio pokyčiams.

Valstybès skatinama žemès naudotojų veikla. Igyvendinant 2007-2013 ir 2014-2020 m.
Kaimo plètros programų priemones, Europos Sajungos (ES) ir valstybès lèšomis mokamos tiesioginès kompensacinès išmokos žemès ūkio veiklos subjektams, savo žemès valdose vykdantiems darbus, padedančius pagerinti žemès ūkio naudmenų ūkines savybes ir padidinti kraštovaizdžio ìvairovę. Pagrindiniai paramos tikslai, susiję su kraštovaizdžio pertvarkymu, - diegti aplinką tausojančią ūkininkavimo politiką, mažinti klimato kaitos neigiamas pasekmes, išsaugoti biologinę ịvairovę (Lietuvos Respublikos..., 2007). Dèl teikiamo finansavimo kai kurie kintantys kraštovaizdžio elementai igyja specialaus tvarkymo teritorijų statusą, t. y. juos galima priskirti ilgam laikotarpiui išsaugotiniems objektams. Tai pagal žemès naudotojų įsipareigojimus ju pateiktose paraiškose paramai gauti finansuojami Kraštovaizdžio tvarkymo programos darbai (veiklos sritys - „Natūralių ir pusiau natūralių pievų tvarkymas“, „Šlapynių tvarkymas“, „Vandens telkinių pakrančių apsaugos juostų tvarkymas"). Pagrindiniai ịpareigojimai tokių natūralių žemés plotų naudotojui: kasmet šienauti arba ganyti gyvulius, išsaugoti pavienius medžius, iškirsti krūmus ir kt. (Lietuvos Respublikos..., 2007b). Kitos finansuojamos priemonès skatina stabiliu kraštovaizdžio elementų tinkamą eksploataciją ir priežiūrą („Melioracijos griovių tvarkymas“) arba naujų kintančių kraštovaizdžio elementų sukūrimą („Pirmas žemès ūkio paskirties žemès apželdinimas mišku“, „Pirmas ne žemès ūkio paskirties ir apleistos žemès ūkio paskirties žemès apželdinimas mišku“). Parama pagal šias bei kitas priemones turi ir netiesiogini poveiki, kadangi žemès naudotojams sudaromos geresnès ekonominès sąlygos atlikti agrarinių teritorijų tvarkymo darbus, nereikalaujančius valdymo instituciju leidimo. Tai - apleistų ir dirvonuojančių žemių grąžinimas žemès ūkio veiklai (atlikus sausinimo sistemų remontą ar kultūrtechninius darbus), apleistų buvusių kultūrinių pievų atkūrimas (žolyno atnaujinimas), sodų íveisimas, esamo kelių tinklo pagerinimas (siekiant užtikrinti patikimą privažiavimą bet kuriuo metų laiku ị kiekvieną sodybą), tinkama melioracijos kanalų ir kitų hidrotechninių įrenginių priežiūra. Šių darbų vykdymu suinteresuoti žemés savininkai ir naudotojai dažniausiai siekia padidinti naudojamos žemès plotą, pagerinti sąlygas mechanizuotiems žemès ūkio darbams ir padidinti žemès ūkinę vertę bei 
išauginamos produkcijos kieki. Visi šie valstybès skatinami darbai turi itakos kintamu kraštovaizdžio elementų ir žemès naudmenų sudèties pokyčiams agrarinèse teritorijose. Pavyzdžiui, pagal Nacionalinès mokejimo agentūros bei Žemès ūkio informacijos ir kaimo verslo centro duomenis $^{*}$, per 2007-2016 m. deklaruotų žemès ūkio naudmenų plotas Lietuvoje padidejo nuo 2643 tūkst. ha iki 2897 tūkst. ha, arba 9,6\%.

Natūralūs (gamtiniai) procesai. Žemès ūkio veiklai nenaudojamuose plotuose dèl drègmès pertekliaus vyksta savaiminè buvusių žemès ūkio naudmenų transformacija $\mathfrak{i}$ kitas naudmenas. Pagal statistinių žemés apskaitos duomenų analizę nustatyta, kad dèl šių priežasčių žemès ūkio naudmenų plotas kasmet gali sumažèti iki 0,6 \%, o teritorijose, kur vykdomi žemès ūkio naudmenas atkuriantys melioracijos darbai, - apie 0,1\% (Bykovienė ir kt., 2014). Siekiant išvengti šių neigiamų procesų, būtinos priemonès, stimuliuojančios žemès naudotojus laikytis ịstatymuose išdèstytų reikalavimų naudoti žemę pagal nustatytą paskirtị ir tausoti žemès ūkio naudmenas, taip pat tinkamai organizuota žemès naudojimo valstybinè kontrolè. Išsamesnè žemès naudojimo analizè leistų nustatyti, kuriuos natūralių arba apleistų žemès ūkio naudmenų sklypus ekonomiškai naudinga pritaikyti intensyviam žemès ūkio naudojimui, o kuriuos tikslingiau apsodinti mišku arba palikti savaiminei renatūralizacijai. Ekologiškai jautriose teritorijose kiekvienos žemès naudmenos perspektyvos (kontūro forma, naudmenos rūšis, panaudojimo būdas ir intensyvumas) turètụ būti nulemtos specialiojo teritorijų planavimo dokumente, perspektyvių žemès naudmenų rūšis ir išsidèstymą išreiškiant kartografiškai plane (pagrindiniame brèžinyje).

Valstybės ir savivaldybių lygmens institucijų reguliuojama žemès naudotojų veikla. Šioms institucijoms priskirtina: Nacionalinė žemès tarnyba prie Žemès ūkio ministerijos ir jos teritoriniai padaliniai; Aplinkos ministerija ir jai pavaldžios îstaigos bei jų struktūriniai padaliniai; savivaldybių administracija. Institucijos išduoda planavimo sąlygas teritorijų planavimo dokumentams rengti, derina ir kai kuriais atvejais tvirtina teritorijų planavimo dokumentus bei techninius statybos projektus, teisès aktų nustatytais atvejais

* Žiūrèta per internetą: http://www.vic.lt/?mid=376 priima sprendimus pakeisti pagrindinę žemès sklypo naudojimo paskirti ar žemès naudmenu sudèti, nustatyta tvarka išduoda leidimus veiklai, keičiančiai žemès naudojimo paskirti ir žemès naudmenų sudètị. Be to, šios institucijos vykdo valstybinę kontrolę - kaip žemės naudotojai savo veikloje laikosi ịstatymų ir kitų norminių teisès aktų, taip pat teritorijų planavimo dokumentu sprendinių. Nustatyta tvarka leidžia reguliuoti kraštovaizdžio formavimo procesą taip, kad jame dalyvautų atitinkamas veiklos sritis išmanantys specialistai, dirbantys valstybès institucijose ir savivaldybès administracijoje, taip pat, rengiant teritoriju planavimo dokumentus, ir suinteresuota visuomenè.

Tokiu būdu reguliuojama žemès naudotojų veikla daugiausia apima stabilių kraštovaizdžio elementų sukūrimą ar panaikinimą (vykdant ìvairias naujas statybas ir esamų statinių rekonstrukciją). Tačiau savivaldybių teritorijų bendruosiuose planuose, valstybinių parkų ir draustinių planavimo schemose ir tvarkymo planuose, kituose specialiuosiuose planuose nustatytos žemès naudojimo sąlygos bei ūkinès veiklos ribojimai turi įtakos ir žemès naudmenų rūšies pakeitimui. Kai kuriais atvejais tokiais planavimo dokumentų sprendiniais siekiama išsaugoti ar net atkurti buvusias natūralias žemès naudmenas ir vienkiemius, kitais atvejais - sukurti naujus stabilius kraštovaizdžio elementus (gyvenamuosius kvartalus, ūkininkų sodybas, rekreacinius statinius, vejo jègaines, kitus ịvairios ūkinès paskirties pastatus) arba drausti vykdyti tam tikrą veiklą (pvz., pastatų statybą ar melioracijos darbus). Šie pakeitimai reikalauja labai gero ekonominio ir ekologinio pagrindimo bei planavimą inicijuojančiu asmenų interesų balanso. Kadangi nauji statiniai ir kiti objektai dažniausiai suplanuojami agrarinèse teritorijose, jau prieš šimtmečius ísavintose žemès ūkiui, ypač svarbu rengiant teritorijų planavimo dokumentus ir priimant sprendimus dèl ju patvirtinimo ịvertinti tai, kaip bus išsaugoti našios dirbamos žemès plotai ir kokią įtaką nustatyti reikalavimai turès žemès ūkio paskirties žemès naudojimo efektyvumui. Sprendžiant iš 1 lentelèje pateiktos žemès naudmenų dinamikos, sąlyginai natūraliomis ne žemès ūkio naudmenomis ir statiniais užimtų plotų skverbimasis į žemès ūkio paskirties teritorijas dar yra labai didelis: per 70 metų miškų, vandens telkinių, pelkių, krūmynų, 
kelių ir užstatytų teritorijų bendras plotas padidejo apie $1 \mathrm{mln}$. ha, o žemès ūkio naudmenų plotas sumažejjo 846 tūkst. ha, arba apie $20 \%$.

Bendrųjų socialinių ir ekonominių pokyčių ittaka žemès ūkio veiklai. Nuo XX a. antrosios pusès kaimo gyvenimo sąlygos sparčiai kito. Ekonominių ir socialinių pokyčių rodikliams priskirtina: gyvenimo kokybès mieste ir kaime skirtumai (darbo užmokestis, investicijos, viešosios infrastruktūros objektai ir pan.), kaimo gyventojų užimtumas, ūkininkavimo būdas, produkcijos išauginimo ir realizavimo galimybès, konkurencija rinkoje, kartų kaitos problemos, kaimo bendruomenių ittaka, vietovès patrauklumas ir kt. Iš šių bendrojo pobūdžio pokyčių didžiausią ittaką agrarinio kraštovaizdžio transformacijai turèjo gyventojų bei darbingo amžiaus žmonių šeimose skaičiaus mažejimas ir jų migracija iš kaimo vietovių $\mathfrak{z}$ miestus, taip pat mokslinè-techninè pažanga, keičianti žemès ūkio gamybos būdą.
Demografinių pokyčiu analizė (panaudoti Visuotinio gyventojų surašymo ir kiti Statistikos departamento skelbiami duomenys) parodè, kad, palyginti su prieškario laikotarpiu, kaimo gyventojų skaičius Lietuvos teritorijoje sumažejo 1396,3 tūkst. žmonių, arba 59,6 \%, o miesto gyventojų skaičius padidejo 1247,7 tūkst. žmonių, arba beveik 2,8 karto (2 pav., 1 lentelè).

Šie procesai neigiamai paveike kraštovaizdžio ivvairovę - kaime liko žymiai mažiau darbingo amžiaus žmonių bei ganomus gyvulius laikančių šeimų, sumažejo bendras šių gyvulių skaičius (pvz., pagal Statistikos departamento duomenis, 1939 m. karvių skaičius buvo 885,0 tūkst., 1989 m. - 847,7 tūkst., 2003 m. - 451,1 tūkst., 2016 m. - 299,7 tūkst.). Dèl to anksčiau tinkamai naudoti - nušienaujami bei nuganomi - nedideli natūralių žalienų plotai palaipsniui apaugo medžiais ir krūmais arba virto nenaudojama žeme.

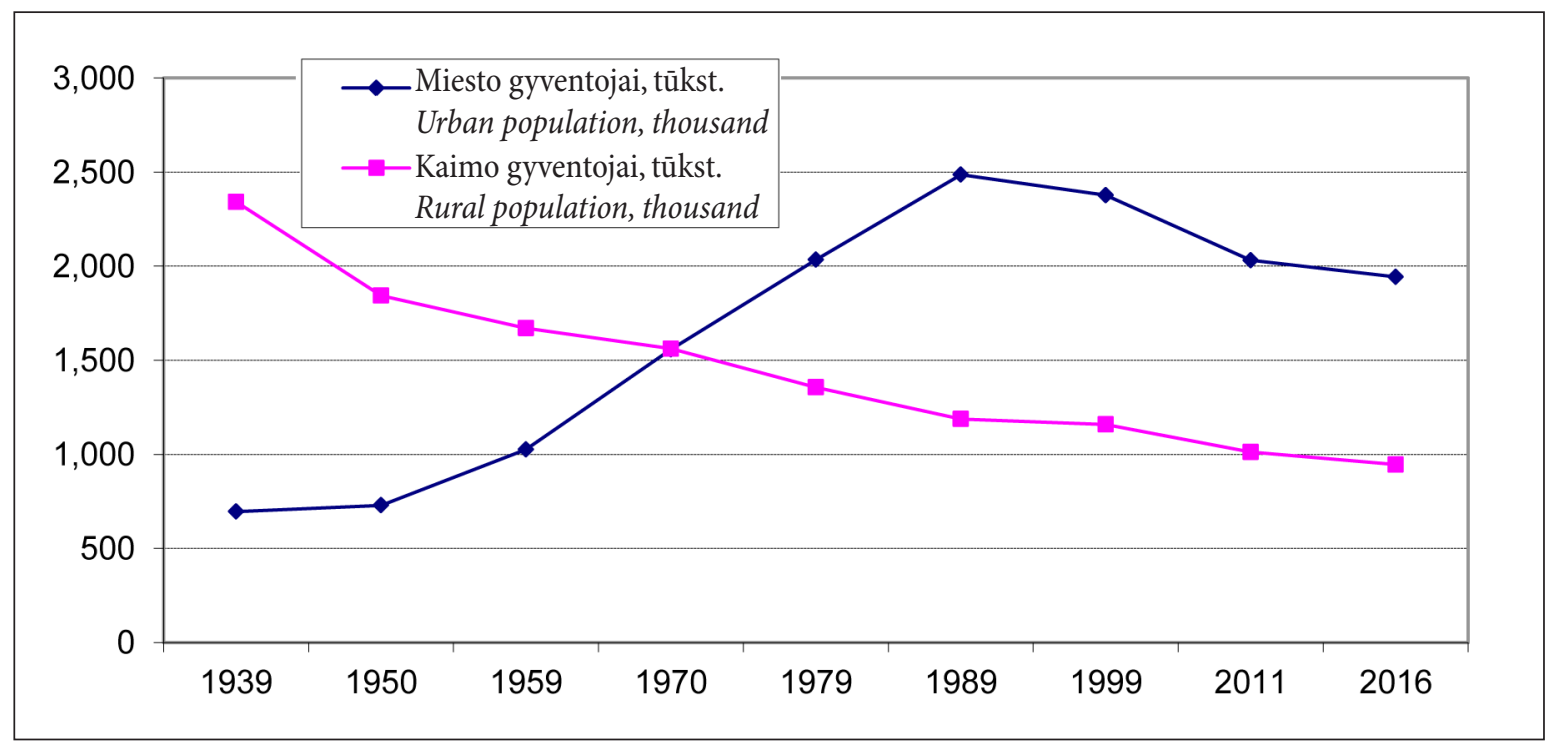

2 pav. Demografiniai pokyčiai

Fig. 2. Demographical information

1 lentelè. Lietuvos miesto ir kaimo gyventojų skaičius metų pradžioje, tūkst. žmonių

Table 1. The number of Lithuanian urban and rural population for the beginning of the year, for thousand people

\begin{tabular}{c|c|c|c|c|c|c|c|c|c}
\hline Metai / Year & 1939 & 1950 & 1959 & 1970 & 1979 & 1989 & 1999 & 2011 & 2016 \\
\hline $\begin{array}{c}\text { Miesto gyventojai } \\
\text { Urban population }\end{array}$ & 695,5 & 729,5 & 1025,9 & 1557,7 & 2034,9 & 2486,8 & 2377,2 & 2031,2 & 1943,2 \\
\hline $\begin{array}{c}\text { Kaimo gyventojai } \\
\text { Rural population }\end{array}$ & 2341,6 & 1843,9 & 1670,8 & 1561,2 & 1356,6 & 1188,0 & 1159,2 & 1012,2 & 945,3 \\
\hline $\begin{array}{c}\text { Iš viso } \\
\text { Total }\end{array}$ & 3037,1 & 2573,4 & 2696,7 & 3118,9 & 3367,5 & 3674,8 & 3536,4 & 3043,4 & 2888,6 \\
\hline
\end{tabular}


Dèl mokslinès-techninès pažangos žemès ūkio gamyba palaipsniui intensyvejo, buvo naudojamos tobulesnès mašinos ir įrengimai, taikomos naujos darbų technologijos. Padideję gamybiniai pajëgumai reikalavo tokių ūkinių vienetų ir tokio dydžio laukų, kuriuose ūkininkauti būtų ekonomiškai efektyvu. Todèl liko nepanaudoti pasèliams smulkūs, nepatogios konfigūracijos, sunkiai privažiuojami ariamosios žemès sklypai; dalis jų buvo apsodinti arba savaime apaugo mišku.

\section{AGRARINIO KRAŠTOVAIZDŽIO POKYČIŲ PASEKMĖS}

Nurodytų priežasčių, dẻl kurių vyksta kraštovaizdžio pokyčiai, ịtaka žemès naudojimui išnagrinèta palyginant žemès naudmenų struktūros dinamiką šalies teritorijoje (2 lentelè). Analizei panaudoti valstybinès žemès apskaitos oficialūs duomenys (iki 1990 m. šią apskaitą vykdè Žemès ūkio ministerijos Žemètvarkos valdyba, vèliau - žemès

2 lentelè. Žemès naudmenų pokyčiai Lietuvoje 1946-2016 m.

Table 2. Land use changes in Lithuania during 1946-2016

\begin{tabular}{|c|c|c|c|c|c|c|}
\hline \multirow[t]{2}{*}{$\begin{array}{l}\text { Žemès naudmenos } \\
\text { Land use }\end{array}$} & \multicolumn{2}{|c|}{ 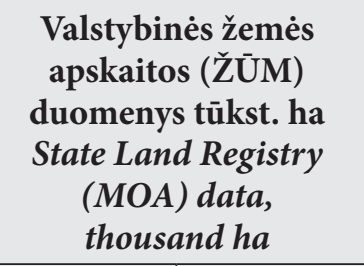 } & \multicolumn{2}{|c|}{$\begin{array}{c}\text { Žemès apskaitos (RC } \\
\text { ir V̌̌F) duomenys } \\
\text { tūkst. ha } \\
\text { Agriculture accounts } \\
\text { (RC and VŽF) data, } \\
\text { thousand ha }\end{array}$} & \multicolumn{2}{|c|}{$\begin{array}{c}\text { Pokyčiai per } 70 \\
\text { metų } \\
(1946-2016) \\
\text { Changes in } 70 \\
\text { years } \\
(1946-2016)\end{array}$} \\
\hline & 19461101 & 19471101 & $\begin{array}{c}(\mathrm{RC}) \\
20140101\end{array}$ & $\begin{array}{c}(\mathrm{VŽF}) \\
20160101\end{array}$ & tūkst. ha & $\%$ \\
\hline 1 & 2 & 3 & 4 & 5 & 6 & 7 \\
\hline $\begin{array}{c}\text { Ariamoji žemė (įskaitant kultūrines } \\
\text { ganyklas, dirvonus, daržus) } \\
\text { Arable land (including cultural } \\
\text { pastures, fallow land, gardens) }\end{array}$ & 2966,3 & 3015,5 & 2925,0 & 3098,4 & $+132,1$ & $+4,5$ \\
\hline $\begin{array}{l}\text { Pievos ir natūralios ganyklos } \\
\text { Meadows and natural pastures }\end{array}$ & 1276,1 & 1262,2 & 478,6 & 320,1 & $-956,0$ & $-74,9$ \\
\hline Sodai / Orchards & 35,6 & 38,6 & 58,2 & 13,2 & $-22,4$ & $-62,9$ \\
\hline $\begin{array}{l}\text { Iš viso žemés ūkio naudmenų } \\
\text { Total of farmland }\end{array}$ & 4278,0 & 4316,3 & 3461,9 & 3431,5 & $-846,5$ & $-19,8$ \\
\hline $\begin{array}{c}\text { Iš jų naudojamos (1946-1947 m. - be } \\
\text { dirvonų, 2014-2016 m. - tik deklaruotos) } \\
\text { Of these used (in 1946-1947 - with- } \\
\text { out fallow land, in 2014-2016 - only } \\
\text { declared ones) }\end{array}$ & 3972,7 & 4019,6 & 2800,3 & 2897,0 & $-1075,7$ & $-27,1$ \\
\hline Miškai / Forests & 1202,4 & 1234,1 & 2130,2 & 2198,5 & $+996,1$ & $+82,8$ \\
\hline $\begin{array}{l}\text { Pelkès ir krūmynai } \\
\text { Swamps and the bush }\end{array}$ & 352,0 & 338,1 & 212,6 & 229,5 & $-122,5$ & $-34,8$ \\
\hline $\begin{array}{l}\text { Vandenys (upès, ežerai, tvenkiniai, } \\
\text { kanalai, kiti vandens telkiniai) } \\
\text { Waters (rivers, lakes, ponds, canals and } \\
\text { other water bodies) }\end{array}$ & 173,1 & 174,3 & 262,5 & 264,4 & $+91,3$ & $+52,7$ \\
\hline $\begin{array}{l}\text { Keliai, gatvès ir aikštės } \\
\text { Roads, streets and squares }\end{array}$ & 190,8 & 185,0 & 131,4 & 104,1 & $-86,7$ & $-45,4$ \\
\hline Užstatytos teritorijos / Built up areas & 101,2 & 102,1 & 182,0 & 238,4 & $+137,2$ & $+135,6$ \\
\hline $\begin{array}{l}\text { Kitos naudmenos ir nenaudojama žemé } \\
\text { Other land and unused land }\end{array}$ & 125,7 & 120,1 & 62,2 & 149,4 & $+23,7$ & $+18,9$ \\
\hline $\begin{array}{l}\text { Bendras plotas pagal žemès apskaitą } \\
\text { The total area according to the land } \\
\text { accounting }\end{array}$ & 6423,2 & 6470,0 & 6530,0 & 6528,6 & $\times$ & $x$ \\
\hline
\end{tabular}


(nekilnojamojo turto) kadastrą tvarkanti imonè (šiuo metu - valstybès i̇monè Registru centras), o nuo 2014 m. - valstybės įmonè Valstybès žemès fondas).

Iš 2 lentelès galima spręsti apie kraštovaizdžio elementų pokyčius, kadangi jų apimtys ir išsidèstymas priklauso nuo žemès naudmenų klasifikacijos. Labiausiai dinamiškos teritorijos yra žemès ūkio naudmenos, miškai ir užstatyti žemès plotai. Nedeklaruotos žemès ùkio naudmenos (ju didžioji dalis - tai apleista ir dirvonuojanti žemè) 2016 m. sudarè apie 534 tūkst. ha. Daugiausia nepanaudotu žemès ūkio produkcijai auginti žemès ūkio naudmenų yra teritorijose su erozijos paveiktais dirvožemiais, iš jų - kalvoto reljefo savivaldybėse, kur vyrauja mažos ūkinès vertès, smulkūs ir mechanizuotam dirbimui nepatogūs žemès ūkio naudmenų kontūrai (Bykovienė ir kt., 2014). Dèl didelès apimties šių žemès plotų tikslingiausią panaudojimą galima nustatyti tik ịvertinus kiekvieno tokio nenaudojamo sklypo dirvožemio potencialųji našumą, investicijų sausinimo sistemų rekonstrukcijai ar kultūrtechniniams darbams galimybes, taip pat natūralių želdinių poreiki toje teritorijoje. Tokios priemonès gali būti igyvendinamos tiek pačių žemès naudotojų pajegomis, tiek teikiant valstybès paramą bei vadovaujantis šių plotų panaudojimą numatančiais specialiaisiais planais.

Bendras miškų plotas Lietuvoje per 70 metų padidejjo 1,8 karto ir pasiekè 2198 tūkst. ha, arba $33,7 \%$ šalies teritorijos. Tai atitinka mokslininku rekomenduotus Lietuvos miškingumo rodiklius. Tačiau miškams įveisti agrarinèse teritorijose ir toliau gali būti perduodami netinkami perspektyvių ùkių veiklai plotai - nenaudojama žemè bei mažo našumo žemès ūkio naudmenos. Remiantis Aleksandro Stulginskio universitete atliktais mažai palankių ūkininkauti žemių naudojimo tyrimais (Abalikštienè ir kt., 2013a; Abalikštienè, 2013b) nustatyta, kad ìveisti mišką žemès ūkio naudmenose ekonomiškai tikslinga tik tuose plotuose, kuriuose per metus išauginamos žemès ūkio produkcijos normatyvinè vertè ne didesnè nei 600-700 Eur/ha (tai atitinka 1,5-1,7 t/ha javų derliaus vertę). Tai rodo, kad miškams perduodamų žemès ūkio paskirties žemių plotas turètų palaipsniui mažèti, kol nusistovès nekintantis žemès ūkio naudmenu ir miškų ploto santykis. Todèl konkrečiose kadastro vietovèse miškų ịveisi- mas turètų būti leidžiamas tik vadovaujantis prieš tai parengtais teritoriju planavimo dokumentais, kompleksiškai nustatančiais šių pagrindinių žemès naudmenų sklypų išsidèstymą.

Užstatytas teritorijas kaimo vietovèje daugiausia sudaro sodybos kaimo gyvenvietèse ir vienkiemiuose. Kaimo gyvenviečių plètros sąlygos ir apimtys yra pakankamai detaliai suplanuotos savivaldybių teritorijų bendruosiuose planuose, taip pat valstybinių parkų ir draustinių tvarkymo planuose. Agrarinio kraštovaizdžio formavimo požiūriu aktualu tobulinti kaimo plètros žemètvarkos projektų ūkininko sodybos vietai parinkti metodiką; šių projektų vidutiniškai per metus (2011-2015 m. duomenys) parengiama po 1,1 tūkst. Visi tokie projektai rengiami tik vienam žemès sklypui (jie turi būti ne mažesni kaip 0,5 ha), nesiejant būsimos sodybos vietos (dažniausiai numatomos naujai kuriamame vienkiemyje) su aplinkiniu kraštovaizdžiu. Metodiškai tikslinga kiekvieno tokio ūkininko ūkio žemès valdoje numatomų statyti gyvenamojo namo ir kitų pastatų išdèstymą spręsti kompleksiškai, rengiant teritorijų planavimo dokumentą viso kaimo ar didesnei teritorijai.

\section{ŽEMĖS NAUDMENŲ IŠDĖSTYMO REGULIAVIMO TEISINIAI ASPEKTAI}

Žemès ūkio naudmenos yra ypatingą svarbą visuomenei turintis gamtos išteklius. Ju išskirtinè reikšmè pabrèžta Konstitucinio Teismo nutarimuose aiškinant Konstitucijos 54 ir 46 straipsnių taikymą. Konstitucinio Teismo išaiškinimuose akcentuojama vertingų žemès ūkio naudmenų tausojimo ir tinkamo žemès naudojimo, išsaugant kraštovaizdi, svarba: „Žemès, kaip riboto ištekliaus, tinkamas naudojimas yra žmogaus ir visuomenès išlikimo ir raidos sąlyga, tautos gerovès pagrindas; jos, kaip gamtos ištekliaus, racionalaus naudojimo užtikrinimas yra viešasis interesas, kuri garantuoti yra valstybès konstitucinè priedermë“ (Lietuvos Respublikos..., 2005; Lietuvos Respublikos..., 2006a); „Pažymètina, kad racionalus žemès naudojimas yra neatsiejamas nuo jos apsaugos, inter alia nuo derlingos dirbamos žemès, kraštovaizdžio išlaikymo. $<\ldots>$ Žemès ūkio paskirties žemè yra išskirtinès vertès ribotas gamtos išteklius..." (Lietuvos Respublikos..., 2006b); „Žemès, mišku ir vandens 
telkinių tinkamas, racionalus naudojimas ir apsauga - Konstitucijos ginamas viešasis interesas" (Lietuvos Respublikos..., 2009). Vadinasi, žemès ùkio naudmenos turi būti tausojamos laikantis ne mažiau griežtų isstatymuose nustatytų reikalavimų, kaip ir kitas išskirtinès reikšmès gamtos išteklius - miškai.

Ilgą laiką aktuali problema buvo miškų ploto atkūrimas iki moksliškai pagrịsto dydžio. Valakų reformos laikotarpiu dabartinèse Lietuvos teritorijoje miškingumas siekè 42-44 \%, 1800 m. - $37 \%, 1900$ m. - 24 \% (Mališauskas, 1985). Pagal G. Pauliukevičiaus ir J. Kenstavičiaus skaičiavimus (Pauliukevičius ir kt., 1995), Lietuvos Respublikos realiai pasiekiamas miškingumas, optimizuojant ekologinę situaciją, yra 33,4 \%. Ivertinant G. Pauliukevičiaus tyrimus (1982), atskirose šalies zonose optimalus miškingumas yra nuo 10-12\% iki daugiau kaip $40 \%$, vidutiniškai šalyje - iki $35 \%$. Pagal S. Karazijos ir V. Vaičiūno tyrimus (Karazija ir kt., 2000), šio laikotarpio optimalus Lietuvos ekologinio miškingumo rodiklis yra $33 \%$. Aplinkos ministro ir žemès ūkio ministro issakymu patvirtintoje Lietuvos miškingumo didinimo programoje (Lietuvos Respublikos..., 2003) nurodyta, kad Lietuvos gamtos apsaugos kompleksineje schemoje (1986) optimalus ekologinis miškingumas buvo nustatytas 33-35\%, kuri pasiekti planuota iki $2015 \mathrm{~m}$. Šiuo metu šalies miškingumas - 33,7 \%, todèl plèsti miškus dèl to mažinant žemès ūkio produkcijai išauginti naudojamus plotus nèra būtinumo. Tačiau isstatymai šiuo metu leidžia kompensuoti už miško žemès sumažinimą žemès ūkio paskirties žeme. Tai nèra pagrịsta žemès ūkio naudmenų, kaip atkuriamo tik melioracijos priemonių dèka gamtos ištekliaus, išsaugojimo požiūriu, nes miškas, priešingai, yra ne tik lengviau atkuriamas, bet ir savaime atsikuriantis gamtos išteklius. Todèl žemès ūkio naudmenų ir miškų ploto santyki reikalinga nustatyti rengiant teritoriju planavimo dokumentus, ịvertinant ekonominius ir ekologinius veiksnius bei tokiu būdu užtikrinant interesų balansą. Taip pat būtina Žemès įstatymo pataisa, nustatanti, kad už našių žemès ùkio naudmenų ploto sumažinimą, nuimant derlingąji dirvožemi, kompensuojama valstybei planavimo organizatorių ar statytojų lešomis vadovaujantis tokiais pačiais principais kaip ir už miško žemès ploto sumažinimą.
Reguliuojant žemès plotų teritorini paskirstymą, t. y. siekiant racionalaus žemès išteklių naudojimo, įvairių ūkio šakų veiklos suderinimas laikantis naudingumo visuomenei principo yra numatytas Teritorijų planavimo įstatyme (Lietuvos Respublikos..., 2004a). Šio ístatymo 8 straipsnyje nurodyta, kad „visuomenès (viešąji) interesą planuojant teritorijas sudaro: $<\ldots>$ 2) kraštovaizdžio, gamtos ir nekilnojamojo kultūros paveldo, žemès ūkio naudmenu su derlinguoju dirvožemiu, miškų, žemės gelmių išteklių, kitų gamtos išteklių apsauga ir racionalus naudojimas, darnus kultūrinio kraštovaizdžio formavimas...." Tai ypač svarbu turint omenyje imperatyvinį teritorijų planavimo dokumentų sprendinių pobūdị. Teritorijų planavimo isstatymo 22 straipsnyje nurodyta: „Neurbanizuotose ir neurbanizuojamose teritorijose parengti ir patvirtinti vietovès lygmens specialiojo teritorijų planavimo žemètvarkos dokumentai ir žemès gelmių naudojimo planai privalomi juos patvirtinusiems subjektams, žemès sklypų valdytojams ir naudotojams, taip pat visiems suplanuotoje teritorijoje veikiantiems fiziniams ir juridiniams asmenims ar kitoms organizacijoms."

Siekiant padèti ūkiams planingiau tvarkyti agrarines teritorijas, reikalingi ūkio teritorijos tvarkymo darbai gali būti numatomi specialiajame žemètvarkos planavimo dokumente - kaimo plètros žemètvarkos projekte, rengiamame ūkio žemès valdai pertvarkyti (šie darbai numatyti Žemès įstatymo 39 straipsnyje). Panaudojant naujausią kartografinę medžiagą, Žemès informacinès sistemoje sukauptus duomenis apie dirvožemius ir kitas žemès savybes, taip pat atlikus tyrimus vietoveje, planavimo specialistai galètu parengti pasiūlymus reikalingiems ūkio teritorijos tvarkymo darbams. Bendrieji žemès išteklių naudojimo klausimai tuo pačiu metu turètų būti sprendžiami savivaldybių ar jų kaimiškųju seniūniju teritorijoms rengtinose žemètvarkos schemose. Kaimo plètros žemètvarkos projektas turètų būti vertinamas kaip ilgalaikių kraštovaizdžio elementų perspektyvinis planas, pateikiantis atitinkamus skaičiavimus reikalingų darbų apimčiai. Rekomenduojama, kad projekto pagrindiniame brèžinyje būtų pažymèta:

- ūkio centrinès sodybos ir ùkiniu pastatu, naudojamų žemès ūkio gamyboje, teritorinis išsidèstymas bei gamybos intensyvumą juose apibūdinančios charakteristikos; 
- planuojamos teritorijos dirvožemiai pagal tipologinius vienetus ir granuliometrinę sudeti, jų melioracinè būklè ir agrocheminès charakteristikos, našumo balai;

- ūkio naudojamų ariamosios žemès ir kultūrinių pievų plotų suskirstymas it panašias savybes turinčius laukus („agroūkinius sklypus“);

- apleistų ir dirvonuojančių buvusių žemès ūkio naudmenų sklypai ir numatomas jų perspektyvinis panaudojimas (grąžinti žemès ūkio veiklai; apsodinti mišku; palikti natūralios būklès);

- žemès plotai, kuriuos žemès sklypų savininkams rekomenduojama apsodinti mišku (vadovaujantis žemés ūkio ministro ir aplinkos ministro ísakymu nustatyta tvarka);

- ūkio žemès valdoje esančios natūralios žemés naudmenos (pievos, ganyklos, medžiu ir krūmų želdiniai, giraitès, pelkès ir šlapžemès, vandens telkiniai), kurios dèl savo apsauginių funkcijų arba dèl kraštovaizdžio ekologinès ịvairovès turi būti išsaugomos, t. y. jos negali būti sukultūrinamos ar paverčiamos kitomis žemès naudmenomis;

- žemès plotai su blogai veikiančiomis sausinimo sistemomis, kai reikalingos priemonès joms pagerinti, taip pat reikalingos priemonès melioracijos grioviams tvarkyti, tiltams, pralaidų ir kitų irrenginių būklei pagerinti;

- ūkio žemès valdoje esančių intensyviai naudojamų kelių tinklas ir reikalingos priemonès vietinès reikšmès kelių sankasoms ar dangoms pagerinti;

- saugotini ir kiti objektai, prie kurių sanitarinès arba apsaugos zonos yra nustatytos konkretizuojant Saugomų teritorijų i̇statyme (Lietuvos Respublikos..., 2001), kituose istatymuose, taip pat Lietuvos Respublikos Vyriausybès nutarimais nustatytus reikalavimus ir apribojimus.

Tokio turinio kaimo pletros žemètvarkos projektų rengimo darbai turètų būti laikomi žemès reformos baigiamuju darbu stadija, skirta sutvarkyti agrarines teritorijas. Tuo atveju šie projektai būtų rengiami iš žemès reformai skirtų lèšų. Be to, gali būti surandami ir kiti finansavimo šaltiniai, susiję su parama žemès ūkio ir kaimo plètrai, kadangi Žemès i̇statymo 39 straipsnio 6 dalyje nustatyta, kad „Žemès ūkio ir kaimo plètros istatyme numatytos paramos žemès ūkio ir kaimo plètrai priemonès turi būti derinamos su kai- mo plètros žemėtvarkos projektų sprendiniais, kai jose numatoma: 1) konkurencingu ūkių žemės valdų formavimas; 2) žemès ūkio naudmenų gerinimas; 3) apželdinimas mišku, kitos kraštovaizdžio formavimo priemonès ir gamtos išteklių apsauga; 4) ekologinis ūkininkavimas; 5) kaimo infrastruktūros plètra; 6) alternatyvi žemès ūkio veikla“.

\section{IŠVADOS}

1. Lietuvos agrarinis kraštovaizdis kinta dèl valstybès vykdomos ar reguliuojamos veiklos, žemès naudotojų ūkinès veiklos, taip pat dèl bendrųu socialinių procesų ir techninès pažangos poveikio kaimo apgyvendinimo sistemai ir žemés ūkio gamybai. Šalies mastu šių pokyčių rodiklius išreiškianti žemès naudmenu plotu dinamika rodo, kad per 1946-2016 m. žemès ūkio naudmenų plotas Lietuvoje sumažèjo 19,8 \%, pelkių, krūmynų ir vandens telkinių - 5,9\%, o miškų plotas padidejo $82,8 \%$, užstatytų teritorijų ir kelių plotas $-17,3 \%$.

2. Dalis agrariniam kraštovaizdžiui būdingu objektų (gyvenvietès, valstybiniai keliai, tarpkaiminiai ir kiti vietinès reikšmès magistraliniai keliai, hidrografinis tinklas, mišku ir pelkių plotai) pasižymi inertiškumu ir tai lemia kultūrinio kraštovaizdžio formavimo galimybes. Todèl teritorijų planavimo dokumentų rengimo taisyklèse turètų būti daugiau dèmesio skiriama metodiniams šios paskirties žemès tvarkymo klausimams išaiškinti - kaip planuoti žemès ūkio naudmenų išdèstymo, rūšies ir panaudojimo intensyvumo pakeitimus ir tinkamai pagrịsti (motyvuoti) šių sąlyginai pastovių elementų pakeitimo (transformacijos) ar pagerinimo poreiki.

3. Valstybès institucijų ir savivaldybių administracijos reguliuojama kraštovaizdị keičianti žemès naudotojų veikla dažniausiai remiasi teritorijų planavimo dokumentų sprendiniais, kuriais igyvendinami programiniuose dokumentuose ir teisès aktuose nustatyti žemės išteklių racionalaus naudojimo reikalavimai. Tačiau, kaip rodo savivaldybių teritorijų žemètvarkos schemų ir kaimo pletros žemètvarkos projektų tyrimai, šie žemètvarkos planavimo dokumentai dažniausiai parengiami tik vienam klausimui spręsti, dèl to juose nepakankamai kompleksiškai ịvertinami ekonominiai, ekologiniai ir socialiniai veiksniai visuomenès intereso požiūriu.

4. Siekiant kompleksiškai spręsti kultūrinio agrarinio kraštovaizdžio formavimo klausimus rekomenduotina, kad visoms kaimiškosioms seniūnijoms (jų 
dalims) arba bent stabilias žemès valdas naudojantiems ūkiams būtų rengiami žemètvarkos schemos ir kaimo plètros žemètvarkos projektai, numatantys: a) reikiamas priemones keliams, sausinimo sistemos ịrenginiams ir kitai techninès infrastruktūros būklei pagerinti; b) žemès ūkio gamybai reikalingų dirbamos žemès laukų formavimą ir rekomenduojamas priemones jų ūkinèms savybèms pagerinti; c) apleistų ir dirvonuojančių žemès ūkio naudmenų sklypu tikslingiausią panaudojimą; d) kraštovaizdžio ekologinei ịvairovei svarbių natūralių žemės naudmenų išsaugojimą ir žemės sklypų, kuriuose tikslinga įveisti mišką, išdèstymą; e) naujai kuriamų ūkininkų sodybų ir kitų reikalingų panaudoti užstatymui žemès sklypų išdèstymą. Toks didesniame plote vykdomas agrarinių teritorijų planavimas leistų padidinti visuomenès poveikio kraštovaizdžio tvarkymui galimybes ir pagerinti projektiniu sprendinių kokybę. Be to, šie žemètvarkos planavimo darbai turètu būti laikomi žemès reformos baigiamųjų darbų stadija ir finansuojami valstybès lèšomis.

5. Rekomenduojama tobulinti teisès aktus, reglamentuojančius svarbių agrarinio kraštovaizdžio komponentų išsaugojimą: a) Žemès ịstatyme numatyti piniginę kompensaciją valstybei už žemès ūkio naudmenų su derlinguoju dirvožemiu pavertimą kitomis naudmenomis; b) Administraciniu nusižengimų kodekse numatyti griežtesnes sankcijas už našių žemès ūkio naudmenų ploto sumažinimą (kai tai pažeidžia Žemès ịstatymo 21 ir 22 straipsnių reikalavimus).

Gauta 20170123

Priimta 20170220

\section{Literatūra}

1. Abalikštienė E., Aleknavičius P. 2013a. Žemès ūkio paskirties žemès naudojimo tendencijos nenašių žemių savivaldybèse. Žemès ūkio mokslai. 20(3): 159-169.

2. Abalikštienè E. 2013b. Lietuvos nenašiu žemiu naudojimo planavimo sistemine analizé: daktaro disertacija. Akademija. 72-73.

3. Aleknavičius P. 2012. Kaimiškujų vietovių tvarkymo reguliavimas. Darnaus vystymosi strategija ir praktika. 1(6): 111-122.

4. Aleknavičius P., Aleknavičius M., Akelaitytè S. 2014. Lietuvos kaimo gyvenamujų vietovių pokyčių tyrimai. Journal of Architecture and Urbanism. 38(2): 161-172.

5. Aleknavičius A., Aleknavičius P., Gurskienè V. 2016. Kaimo plètros žemètvarkos projektų porei- kis tvarkant ūkių teritorijas ir jų rengimo metodika. Žemés ūkio mokslai. 23(1):36-46.

6. Balevičiūtè A., Veteikis D. 2012. Renatūralizacijos pokyčiai Lietuvos kraštovaizdyje 1995-2010 metais. Geografija. 48(2): 132-144.

7. Bykovienè A., Pupka D., Aleknavičius A. 2014. Žemès ūkio naudmenų apskaita ir pokyčių analizè Lietuvoje. Žemés ūkio mokslai. 21(4): 250-264.

8. Kaimo plètros žemètvarkos projektų rengimo ir igyvendinimo taisyklès, patvirtintos LR žemès ūkio ministro ir LR aplinkos ministro isakymu. 2004 m. rugpjūčio 11 d. Nr. 3D-476/D1-429. Valstybès žinios. 2004, Nr. 127-4581.

9. Karazija S., Vaičiūnas V. 2000. Ekologinis mišku vaidmuo Lietuvoje. Kaunas. 152 p.

10. Lietuvos Respublikos Konstitucija. Priimta Lietuvos Respublikos piliečiu $1992 \mathrm{~m}$. spalio 25 d. referendume. Prieiga per internetą: http://www3.lrs.lt/ home/Konstitucija/Konstitucija.htm

11. Lietuvos Respublikos Konstitucinio Teismo $2003 \mathrm{~m}$. rugsèjo 30 d. nutarimas. Valstybès žinios. 2003. Nr. 93-4223.

12. Lietuvos Respublikos Konstitucinio Teismo $2005 \mathrm{~m}$. gegužès 13 d. nutarimas. Valstybès žinios. 2005. Nr. 63-2235.

13. Lietuvos Respublikos Konstitucinio Teismo $2006 \mathrm{~m}$. kovo 14 d. nutarimas. 2006a. Valstybès žinios. Nr. 30-1050.

14. Lietuvos Respublikos Konstitucinio Teismo 2006 m. kovo 30 d. nutarimas. 2006b. Valstybès žinios. Nr. 371319.

15. Lietuvos Respublikos Konstitucinio Teismo $2009 \mathrm{~m}$. birželio 22 d. nutarimas. Valstybès žinios. 2009. Nr. 75-3074.

16. Lietuvos Respublikos aplinkos apsaugos ịstatymas. $2004 \mathrm{~m}$. balandžio 13 d. Nr. I-2223. 1992. Valstybès žinios. Nr. 5-75.

17. Lietuvos Respublikos mišku istatymas - 200104 10, Nr. IX-240. 1994. Valstybès žinios. Nr. 96-1872; 2001, Nr. 35-1161.

18. Lietuvos Respublikos saugomų teritorijų ịstatymas. 2001 m. gruodžio 4 d. Nr. IX-628. Valstybés žinios. 2001. Nr. 108-3902.

19. Lietuvos Respublikos teritoriju planavimo istatymo pakeitimo istatymas. $2004 \mathrm{~m}$. sausio $15 \mathrm{~d}$. Nr. IX-1962. 2004a. Valstybès žinios. Nr. 21-617.

20. Lietuvos Respublikos žemès ịstatymo pakeitimo istatymas. 2004 m. sausio 27 d. Nr. IX-1983. 2004b. Valstybès žinios. Nr. 28-868.

21. Lietuvos Respublikos Vyriausybès $2004 \mathrm{~m}$. gruodžio 1 d. nutarimas Nr. 1526 „Dèl Lietuvos kraštovaizdžio politikos krypčių aprašo patvirtinimo“. Valstybès žinios, 2004c. Nr. 174-6443.

22. Lietuvos Respublikos aplinkos ministro ir žemès ūkio ministro $2002 \mathrm{~m}$. gruodžio 2 d. ísakymu Nr. 616/471 patvirtinta Lietuvos miškingumo didinimo programa. 2003. Valstybès žinios. Nr. 1-10. 
23. Lietuvos kaimo plètros 2007-2013 metu programa. 2007a. Prieiga per internetą: http://www.zum.lt/ documents/kaimo_pletros_depart/KPP_20072013_(LT_2010-12-02).pdf

24. Lietuvos Respublikos žemès ūkio ministro $2007 \mathrm{~m}$. balandžio $6 \mathrm{~d}$. i̇sakymas Nr. 3D-152 „Dèl Lietuvos kaimo plètros 2007-2013 metų programos priemonès "Agrarinès aplinkosaugos išmokos" programų „Kraštovaizdžio tvarkymas“, „Ekologinis ūkininkavimas“ ir „Rizikos“vandens telkinių būklès gerinimas“ igyvendinimo taisyklių patvirtinimo“. 2007b. Valstybés žinios. Nr. 41-1561.

25. Lietuvos Respublikos teritorijos bendrasis planas. Patvirtintas Lietuvos Respublikos Seimo $2002 \mathrm{~m}$. gruodžio 29 d. nutarimu Nr. IX-1154. Valstybės žinios. 2002. Nr. 110-4852.

26. Mališauskas V. 1985. Racionalus gamtos ištekliu naudojimas. Vilnius: Mokslas. 208 p.

27. Pauliukevičius G. 1982. Miškų ekologinis vaidmuo. Vilnius: Mokslas. 112 p.

28. Pauliukevičius G., Kenstavičius J. 1995. Ekologiniai mišku teritorinio išdestymo pagrindai: monografija. Vilnius. 289 p.

29. Pažangaus ūkininkavimo taisykless ir patarimai. Antrasis pataisytas ir papildytas leidimas. 2007. Prieiga per internetą: https://zum.lrv.lt/uploads/ zum/documents/files/LT_versija/Veiklos_sritys/ Maisto_sauga_ir_kokybe/Nitratu_direktyvos_igyvendinimas/PUTP_leidinys_2007.pdf

30. Ribokas G., Milius J. 2001. Agrarinès žemènaudos transformacijos XX a. sudètingų ūkinių sąlygų teritorijose. Geografija. 37(2): 65-72.

31. Ribokas G., Kriaučiūnas E. 2012. Rytų Lietuvos žemėnaudos pokyčiai Vilniaus miesto ittakos kontekste. Ekonomika ir vadyba: aktualijos ir perspektyvos. 3(27): 156-163.

32. Žemès ükio maisto ūkio, žuvininkystès moksliniu tyrimu ir taikomosios veiklos projekto „Kaimo plètros žemètvarkos projektu ūkio žemés valdai pertvarkyti techninis ir metodinis pagrindimas": 2015 m. galutinè ataskaita. 2015. ASU.

33. Žemès ūkio maisto ūkio, žuvininkystès moksliniu tyrimu ir taikomosios veiklos projekto „Žemès naudojimo priemoniu mokslinis pagrindimas": $2011 \mathrm{~m}$. baigiamoji ataskaita. 2011. LŽUU.

\section{Pranas Aleknavičius}

\section{FACTORS INFLUENCING AGRARIAN CULTUR- AL LANDSCAPE CHANGES IN LITHUANIA}

\section{Sum mary}

The agrarian cultural landscape is understood as a rural landscape having agricultural character, the formation of which was influenced by the rational management of the territory and land improvement measures. In agricultural land areas, according to the specifics of production organization (when using this land), the descrip- tion of the landscape should include farm land holdings, territorial management system components (houses, roads, land reclamation equipment, cultivated fields, gardens, meadows and pasture plots), as well as water bodies situated in such areas at a particular ratio, protective plantations and other natural or relatively natural farming land plots.

From the point of view of the rational land use regulation, there are two elements of the agrarian landscape: stable (long-term) and variable (relatively unstable).

Stable elements are considered to be: natural objects (landscape, rivers, streams, lakes, etc.) and anthropogenic, man-made objects - farmsteads, agricultural and other types of buildings, roads, dams, canals, ditches, and hydraulic structures. Some of these elements were salvaged from territorial reorganization carried out during the Wallach reform, others appeared due to the inter-war land reform or during the period of the total land reclamation works carried out after the Second World War.

All stable anthropogenic landscape elements are characterized by the fact that at present their creation in a new location or their redevelopment is possible only at a very limited extent, since such works require large capital investments, in addition to the fact that it is necessary to develop a spatial planning document and (or) technical project.

The changing landscape elements are: arable land fields, garden plots, areas overgrown with grassy vegetation, including plots of land uncultivated more than two years (which are defined as abandoned land, fallow land, perennial grass crops, meadows and natural pastures), other farming lands registered in the real estate cadastre. The conversion of these land areas to other land is relatively dynamic and takes place as a result of both natural processes and human activities.

The research goal is to describe the changes of agrarian landscape components in Lithuania during the period of large-scale land reclamation works carried out for decades to the present day, to consider changes affecting the causes and possibilities to regulate the development of agricultural landscape formation.

Part of typical agrarian landscape objects (settlements, state, between-village and local trunk roads, hydrographical networks, forest and wetland areas) are characterized by inertia, and it determines the cultural landscaping opportunities.

An analysis of the reasons for agrarian landscape changes distinguished the following types of reasons:

1) The state-run complex land reclamation works;

2) State-encouraged land users' activity;

3) Natural (nature) processes;

4) Land users' activity regulated by state and municipal institutions; and

5) Impact of general social and economic changes on agricultural activities. 
Two periods can be distinguished in Lithuania's history when the state carried out waterlogged land drainage works by means of open ditches (between the wars) and by means of drainage (during the period between the years 1960 and 1990). In the second period, the works were special in that the entire reclaimed territory was managed as a complex process by converting or creating infrastructure necessary for agricultural activities. In agricultural areas, through implementation of previously developed land management projects, not only regular-sided cultivated fields adapted for efficient work of agricultural machinery were formed, but also new roads with the roadbed and firm grip were constructed and cultivated meadows and pastures were arranged. In addition, old farms were moved with the help of the state funds, and support for the setting up of rural settlements was given. A total of 2664 thousand ha, or 84 percent of wetlands fund, were drained in Lithuania. These comprehensive land reclamation works carried out by the state had an intensified agricultural production potential for a long period: allowed to preserve farmland, improve the economic characteristics of the soil, and increase land productivity. From the agrarian landscaping point of view, they mainly influenced the creation of technical infrastructure of areas used for the modern rural accommodation system and agricultural activities.

By implementing the Rural Development Programme measures for the years 2007-2013 and 20142020, direct compensation payments are being paid by the European Union (EU) and state funds to agricultural entities who carry out in their land holdings the work helping to improve farmland and to increase the economic characteristics of landscape diversity. The main aims of assistance related to the restructuring of the landscape are to promote environmentally friendly farming policies, to mitigate negative effects of climate change and protect biological diversity. Thanks to the funding, some of the changing landscape elements acquired a special management area status, i. e. they can be attributed to long-term preserved objects.

In areas unoccupied for agricultural activities, spontaneous transformation of former agricultural lands to other land uses is going on due to excessive moisture. In order to avoid these negative processes, it is necessary to comply with the requirements set out by laws to use the land according to the purpose and to preserve agricultural land. Also, those receiving public assistance under the Landscape Management Programme and other measures are required to comply with the statutory requirements for the proper use and handling of natural and semi-natural grasslands and wetlands.

State and municipal authorities issue planning conditions for the preparation of territorial planning documents, coordinate and, in some cases, approve territo- rial planning documents and technical construction projects, take decisions to change the main purpose of the land plot or land use composition (in cases determined by applicable laws), issue permits for the activity modifying land use purpose and land use composition. It allows to adjust the landscape formation process (according to the set procedure) so that the knowledgeable professionals of their respective fields, who work in state institutions and municipal administration, should participate in it, as well as the public concerned should participate in the preparation of territorial planning documents.

Thus, regulated land users' activities mainly include creation or liquidation of stable landscape elements (in a variety of new construction and reconstruction of existing buildings). However, land use conditions and restrictions on economic activities set out in the general plans of municipal areas, in the planning schemes and management plans of national parks and reserves as well as in other special plans affect the type of land use change as well. These changes require a very good economic and ecological justification as well as balance of persons' initiating planning interests.

Other activity carried out by users of land in agricultural areas includes such landscaping which is not regulated by territorial planning documents and due to which the decision from the observance of the administrative authorities is unnecessary. Land owners and users interested in the execution of these works typically seek to increase the area of the used land, to improve the conditions for mechanized agricultural works and increase the economic value of land as well as the quantities of grown products.

General social and economic changes in agricultural activities usually are made by migration of population from rural to urban areas, as well as scientific and technical progress replacing agricultural production. Demographic change analysis showed that compared with the pre-war period, the rural population of the territory of Lithuania decreased by $1,396.3$ thousand people, or 59.6 percent, while urban population increased by $1,247.7$ thousand people, or almost 2.8 times. Due to the scientific-technical progress, agricultural production gradually intensified, more sophisticated machinery has been used, and new work technologies have been applied. Increased production capacities demanded such economic entities and such size of the fields in which the farming was cost-effective. Therefore, small, uncomfortably configured as well as limited-access arable lands remained unused; some of them have been afforested or naturally overgrew with forests.

The most dynamic areas are agricultural lands, forests and urbanized areas. During the period between the years 1946 and 2016, agricultural land area in Lithuania decreased by 19.8 percent. In 2016 , the undeclared 
agricultural land (the majority of which was abandoned and fallow land) amounted to 534 thousand ha. The total forest area in Lithuania during the 70 years increased by 1.8 times and reached 2,198 thousand ha, or 33.7 percent of the country's territory. In the future, agricultural land area transferred to forests should gradually decrease to a stable agricultural land and forest area ratio.

Agricultural land is a natural resource with a special importance to the public. It should be treasured in accordance with at least as stringent statutory requirements as are applied to other exceptionally important natural resource - forests. The agricultural land and forest area ratio should be determined while preparing territorial planning documents assessing the economic and ecological factors and thus ensuring the balance of interests. An amendment to the Land Law is also necessary, establishing that fertile agricultural area reduction and removal of fertile soil should be compensated to the state by the organizers' or builders' planning funds in accordance with the same principles as those used for forest area reduction.

In order to tackle cultural agrarian landscaping issues in a comprehensive manner, it is recommended that all rural sub-districts (their parts) or at least farms using only stable land holdings should be prepared landuse planning documents - land management schemes and rural development projects, providing: a) necessary measures for road drainage systems, equipment and other technical infrastructure amelioration; b) agricultural inputs for cultivated fields formation and recommended measures to improve their economic characteristics; c) the most targeted use of abandoned and fallow agricultural land plots; d) natural land use conservation important for landscape ecological diversity and the layout of land plots appropriate for afforestation.

Land use planning document preparation works of such content should be considered the land reform in the final stage of work for agrarian territories. In such case, rural development planning projects would be developed from land reform funds. Such planning of agrarian territories in a larger area carried out with the help of public funds would increase the possibilities of public impact on landscape management and improve the quality of design solutions.

Keywords: agricultural land, land use, technical infrastructure, agrarian landscape, ecological diversity 